International Journal of Built Environment and Sustainability Published by Penerbit UTM Press, Universiti Teknologi Malaysia

IJBES 7(I)/2020, 37-45

\title{
Integration of Structures in Students' Design solutions: A Tool for Assessment
}

\author{
Prabhjot Singh Sugga \\ Department of Architecture, School of Planning and Architecture, New Delhi, India \\ Email:ps.sugga@spa.ac.in \\ Gaurav Raheja \\ Department of Architecture and Planning, Indian Institute of Technology, Roorkee, India. \\ Sanjay Chikermane \\ Department of Civil Engineering, Indian Institute of Technology, Roorkee, India.
}

\begin{abstract}
Traditional teaching practices are often questioned over their failure to generate interest and profound understanding of structures among students that further affect its integration in design solutions. Alternative teaching practices though claim to be more effective, need a sound evaluation measured through assessment of the level of integration of structures in design solutions- the ultimate objective of such courses. This paper evaluates the integration of structures in design solutions of architecture students. The integration assessment framework used for evaluation is based on building systems approach across three dimensions of performance, physicality and visual. It has been developed after comparing four prior frameworks with a 4-point scale and customized to suit the context of the academic environment. The framework offers flexibility in its use for different technical knowledge levels for each successive year of Bachelor of architecture program. The expert opinion followed by testing on design samples from all the program years further refined the framework. The study was then scaled up to include students from first to fourth years for three architecture schools that have completely different institutional environment. The findings revealed that including structural resolution in a design studio mandate may result in higher resolution of structures in design solutions but it is the building typology and student interest that may result in higher visual integration of structures in design solutions. Furthermore, the institutional environment effects can be seen in the setting of studio mandates where architecture school in technical campus laid more emphasis on resolutions of structures and services when compared to other architecture schools.
\end{abstract}

(C) 2020 Penerbit UTM Press. All rights reserved

\author{
Article History \\ Received: 12 May 2019 \\ Received in revised form: 11 November 2019 \\ Accepted: 15 December 2019 \\ Published Online: 31 December 2019
}

Keywords:

Structures integration, teaching practices for structures, architectural education, Design studios

\section{Corresponding Author Contact:}

ps.sugga@spa.ac.in

DOI: $10.11113 /$ ijbes.v7.n1.418

\section{Introduction}

The long-standing debate over teaching methods and curriculum for structures courses (Uihlein 2013) in architectural education continue to produce new alternative teaching practices. The debate stems from the use of traditional teaching practices that may be reasons for architecture students' disinterest in structures courses (Charleson 2005) and, their difficulty in understanding structural concepts (Chiuini 2006) that further affects its integration in design solutions as well as their professional competence. Academics for long have questioned such traditional practices that are watered-down versions of engineering disciplines, for its relevance in the context of architectural education (Black \& Duff 1994) and not accounting for the 
difference in the ways of learning by architecture students over others (Salvadori 1980). While these courses do not intentionally make another engineer out of an architect, their aim is to enable the student to utilize structures effectively in their designs through its more profound and intuitive understanding, rather than superficial familiarity. In professional practice, such understanding may help with effective communication and coordination with engineers for better integration of structures with other building systems, which eventually can lead to architecturally, and technically sound, efficient as well as economically viable buildings.

The question, however still remains about the effectiveness of one teaching practice over the other - between the alternative or traditional practices for teaching structures courses in architecture. Since the integration of structures knowledge into design solutions is the greater objective, a deeper insight into the level of integration of structures in student design solutions would help in making informed decisions on teaching practices of structures as well as setting design studio mandates. In a review of 30 documented and observed alternative teaching practices by the author, most of them have measured their success based on student feedback and personal observations. In few cases where the assessment was made on the integration of structures in design solution but the criteria remained subjective and selective rather than holistic, even though the state of integration has been addressed in professional space through diverse approaches by the various author (Rush 1986; Bachman 2004; Charleson 2005) in past. There is, however, limited research for its understanding in Academic space (Borill 1991), where students learn structures knowledge in successive years of their program and studio mandates, as well as building typologies, affect student's design solutions that remain unbuilt and partially resolved by professional standards.

\subsection{Idea of Integration}

In a building systems approach, Integration is a quality of the creative process of building design whether achieved consciously or otherwise (Rush 1986) through a combination of rule systems along with logic and chance guided by creativity and intuitivism achieving harmony (Borill \& Bovill 1991). It is a complex problem with no direct algorithmic solution; rather it is a play of cooperation between building systems interlinked with Architect's discernment and decision-making with the aid of both logical and intuitive minds. Architects draw inspiration from all walks of life including ideal geometries, structures, mathematical models and social archetypes (Tshumi 2005) to resolve 'illstructured'(Jonassen 1997) or 'wicked' design problems. Specifically, Integration of Structures refers to the arrangement of the structure in conjunction with other building systems and architectural design (Salvadori \& Heller 1986; Uihlein 2015). It is also a function of 'design and construction processes' that calls for the clear communication and collaboration between architects, engineers and other stakeholders, right from early design stages and, includes project sourcing, professional interactions and ideas sharing(Rush 1986). The inseparability between Structures and
Architecture can be traced ancient treatise on architecture -Da Architectura, where the trio logy of Strength, Durability and Beauty form the three principles of good architecture (Morgan 1960). The increasing complexity of building due to the emergence of new typologies with the advancement in the science of material and technologies as well as sensitivity to the ecology and environment divided the 'building' profession into specialized areas such as architecture and structural engineering. Current times demand collaboration between allied professions of building industry for well-integrated and financially competitive buildings.

With energy and environment as the main concern and our increasing dependence on technology in design, Ecological concerns and Technological developments constitute Contemporary issues related to integration in building systems (Bachman 2004). Building systems, that can be classified into 4-5 types (Exterior, Interior, Services, Structures, and Site) (Bachman 2004), can integrate along three dimensions: Performance, Spatial and Visual (Rush 1986). Performance is an efficiency parameter addressing integration for space, building environment and building efficiency. Spatial integration is based on the proximity of different systems in a given space while visual integration refers to the aesthetics component achieved by the degree of exposure of any building system. The highest state of the confluence of structure and architecture is, what master builders of 20the century such as Nervi, Candela, Otto and Isler refer to as 'Structural art'. Billigton describes the structural art as the synthesis of Elegance, Efficiency and Economy (Billington 1983) the cross cutting issues for the above said three dimension of integration. Figure 1 summarizes the concept of integration of structures in Architecture.

\section{Methodology}

To make an assessment framework, the authors began by comparing five different integration frameworks on their unique organizing principles, choice of parameters and scale to qualitatively or quantitatively evaluate integration for different building systems. The proposed framework internalizes the constraints of the academic environment and imparts flexibility based on knowledge levels of students from different years. It compares structural systems with 3 other building systems: exterior, interior and services on performance, physical and visual dimensions. A 4-point scale is introduced for the ease of assessments. Refinements are done after experts' inputs and testing on 11 design solutions from different years. Flexibility in usage is achieved after normalizing the services and structures knowledge and design studio mandates for 4 years of architecture program after reviewing of syllabuses of 8 architecture schools in India. This allows omitting certain parameters for lower years. Finally, taking around 30 samples of design solutions each from 1 to 4 years across 3 schools with diverse institutional setting scaled the study up. Data on Studio mandates, curriculum and studio team expertise is taken separately and compared with the assessment results for analysis. Effect of an institutional setting is also considered in the analysis. 


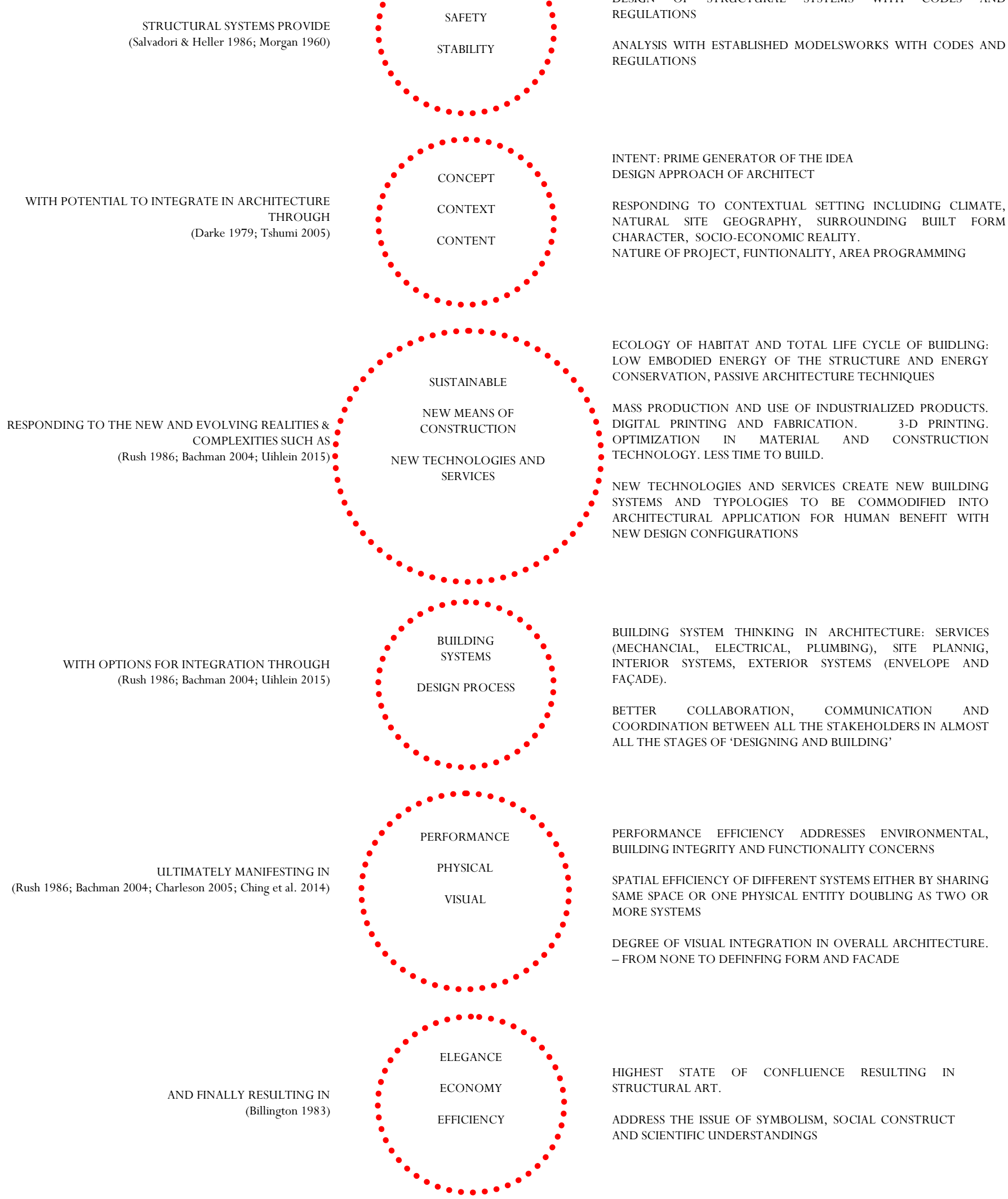

STRUCTURAL CONSIDERATIONS WITH UNDERSTANDING OF STRESSES, LOADS, MATERIAL PROPERTIES, STRUCTURAL SYSTEMS

DESIGN OF STRUCTURAL SYSTEMS WITH CODES AND REGULATIONS

ANALYSIS WITH ESTABLISHED MODELSWORKS WITH CODES AND

INTENT: PRIME GENERATOR OF THE IDEA IGN APPROACH OF ARCHITECT CHARACTER, SOCIO-ECONOMIC REALITY.

NATURE OF PROJECT, FUNTIONALITY, AREA PROGRAMMING

ECOLOGY OF HABITAT AND TOTAL LIFE CYCLE OF BUIDLING: LOW EMBODIED ENERGY OF THE STRUCTURE AND ENERGY MASS PRODUCTION AND USE OF INDUSTRIALIZED PRODUCTS. DIGITAL PRINTING AND FABRICATION. 3-D PRINTING. OPTIMIZATION IN MATERIAL AND CONSTRUCTION TECHNOLOGY. LESS TIME TO BUILD.

NEW TECHNOLOGIES AND SERVICES CREATE NEW BUILDING TYPOLOGIES TO BE COMMODIFIED INTO ARCHITECTURAL APPLICATION FOR HUMAN BENEFIT WITH NEW DESIGN CONFIGURATIONS FAÇADE)

BETTER COLLABORATION, COMMUNICATION AND COORDINATION BETWEEN ALL THE STAKEHOLDERS IN ALMOST ALL THE STAGES OF 'DESIGNING AND BUILDING'

PERFORMANCE EFFICIENCY ADDRESSES ENVIRONMENTAL, G AS TWO OR DEGREE OF VISUAL INTEGRATION IN OVERALL ARCHITECTURE. FROM NONE TO DEFINFING FORM AND FACAD

HIGHEST STATE OF CONFLUENCE RESULTING IN

ADDRESS THE ISSUE OF SYMBOLISM, SOCIAL CONSTRUCT AND SCIENTIFIC UNDERSTANDINGS

Figure 1: Understanding of Integration of Structures in Architecture (Author, 2019) 


\section{$2.1 \quad$ Comparing Integration Frameworks}

The ultimate objective of Integration between different building systems is to achieve Elegance, Efficiency and Economy of Design, construction and Operations, in the light of contemporary challenges of Energy \& environment, new technologies \& services and emerging typologies by accommodating designer's intent and knowledge- all at every level of design-construction processes through collaboration. The frameworks, should, therefore, address these attributes of integration based on their unique organizing principles, choice of parameters and scale to qualitatively or quantitatively evaluate integration for different building systems and/or process of design and construction with the flexibility of considering the designer's intent and building typologies. Table 2 compares 5 frameworks (Rush, Borill, Bachman, Charleson and Ching) for their principle, parameters and building systems as well as rating systems.

\subsection{Integration Assessment Framework}

\subsubsection{Theoretical Construct}

Subjectivity inherits any assessment of buildings and its architecture since it is shaped by assessor's background, knowledge and orientation, which is further bound to change with time for the same building (Charleson 2005). However, a holistic framework can reduce the degree the subjectivity. This framework is essentially built on the lines of Rush's framework with new realities pointed out by Bachman's idea of integration. Borill's deeper understanding of constraints of the academic environment due of limited knowledge and experience of students that results in mostly conceptual and spatially resolved designs solution with little or no information on structural, services and interiors systems, is applied to reorient rush's framework for academic use. Finally, the proposed framework integrates concepts from Charleson's and Ching's framework that gives it a strong architectural focus. The framework is flexible to be applied to design solutions from all the years of architectural program and building typologies. The Proposed framework compares all the four building systems (Structures, Envelope or building exterior, building interior and mechanical or services) for three-level of integration: performance, proximity or physical and visibility or visual. The final matrix represents the interaction of the structural system with the rest of three other systems (Exterior, Interior and Services) for three dimensions of integration (Performance, Physical and Visual). Not all the building systems and sub-systems in the matrix will have indicators for different parameters and sub-parameters; only the one relevant from the perspective of the structure fill up the matrix. The same matrix is converted into a tabular form for easy use for data assessment purposes as shown in Table 3.

The ultimate objective of Integration between different building systems is to achieve Elegance, Efficiency and Economy of Design, construction and Operations, in the light of contemporary challenges of Energy \& environment, new technologies \& services and emerging typologies by accommodating designer's intent and knowledge- all at every level of design-construction processes through collaboration.

\subsubsection{Scale}

The 4 point scale is derived from Rush's Charleson and Ching's framework that defines the relationship of the structural system with other systems for the dimension of performance as either one of conflict, neutrality, active support or progenitor. For physical integration, the Rush's 5 point scale (separate, touch, connected, meshed and union) is modified to 4 points (touch and connected taken as one) for parity and for visual integration the degree of visuality along with level of modification to structural system in building exterior defines the scale (not visible, visible but modified, visible and supports architecture with much modification and primary generator of the form). Table 1 shows the summary of scales for different level of integrations.

Table 1: Scales Explanation Summarized (Author, 2019)

\subsubsection{Factors affecting Flexibility of use of Framework}

\begin{tabular}{|c|c|c|c|c|c|}
\hline \multirow[t]{2}{*}{ Scale } & \multicolumn{3}{|c|}{ Rating for Performance Integration } & \multirow{2}{*}{$\begin{array}{l}\text { Physical } \\
\text { Integration }\end{array}$} & \multirow{2}{*}{$\begin{array}{l}\text { Visual } \\
\text { Integration }\end{array}$} \\
\hline & $\begin{array}{l}\text { Spatial, } \\
\text { Environmental }\end{array}$ & $\begin{array}{l}\text { Building } \\
\text { Integrity }\end{array}$ & $\begin{array}{l}\text { Constructabilit } \\
y\end{array}$ & & \\
\hline 1 & $\begin{array}{l}\text { Conflict: } \\
\text { inhibits } \\
\text { performance }\end{array}$ & $\begin{array}{l}\text { No } \\
\text { rationale/ } \\
\text { Complianc } \\
\text { e with } \\
\text { Fundamen } \\
\text { tals }\end{array}$ & $\begin{array}{l}\text { Material/ } \\
\text { construction } \\
\text { not } \\
\text { considered }\end{array}$ & $\begin{array}{l}\text { Touching: } \\
\text { systems are } \\
\text { overlapping }\end{array}$ & $\begin{array}{l}\text { Concealed: } \\
\text { Structure is } \\
\text { not exposed }\end{array}$ \\
\hline 2 & $\begin{array}{l}\text { Neutral: } \\
\text { Does not } \\
\text { affects } \\
\text { performance }\end{array}$ & $\begin{array}{l}\text { Basic } \\
\text { configurati } \\
\text { on (grid/ } \\
\text { planes, } \\
\text { etc.) with } \\
\text { appropriat } \\
\text { e spans in } \\
\text { place }\end{array}$ & $\begin{array}{l}\text { Contempora } \\
\text { ry material } \\
\text { and } \\
\text { construction } \\
\text { ideas }\end{array}$ & $\begin{array}{l}\text { Connected: } \\
\text { systems are } \\
\text { connected } \\
\text { with frames, } \\
\text { etc. }\end{array}$ & $\begin{array}{l}\text { Consonance: } \\
\text { Structure } \\
\text { defines form } \\
\text { but not part } \\
\text { of exterior } \\
\text { or interior }\end{array}$ \\
\hline 3 & $\begin{array}{l}\text { Supportive: } \\
\text { Helps in } \\
\text { improving } \\
\text { performance } \\
\text { thru sizing, } \\
\text { configuration } \\
\text { \& detailing }\end{array}$ & $\begin{array}{l}\text { Basic } \\
\text { Member } \\
\text { sizing \& } \\
\text { choice of } \\
\text { appropriat } \\
\text { e system } \\
\text { with } \\
\text { material }\end{array}$ & $\begin{array}{l}\text { Materiality } \\
\text { and } \\
\text { technology } \\
\text { compliment } \\
\text { s structural } \\
\text { system }\end{array}$ & $\begin{array}{l}\text { Meshed: } \\
\text { systems are } \\
\text { of different } \\
\text { material but } \\
\text { intertwined }\end{array}$ & $\begin{array}{l}\text { Synthesis/ } \\
\text { Contrast: } \\
\text { Structure } \\
\text { forms part of } \\
\text { overall } \\
\text { aesthetics }\end{array}$ \\
\hline 4 & $\begin{array}{l}\text { Primary } \\
\text { Generator/ } \\
\text { Leading: } \\
\text { actively } \\
\text { defines and } \\
\text { phenomenall } \\
\text { y improves } \\
\text { the } \\
\text { performance }\end{array}$ & $\begin{array}{l}\text { Detailed } \\
\text { structural } \\
\text { design } \\
\text { with } \\
\text { calculation } \\
\text { s }\end{array}$ & $\begin{array}{l}\text { Materiality } \\
\text { and } \\
\text { technology } \\
\text { becomes } \\
\text { part of } \\
\text { construction }\end{array}$ & $\begin{array}{l}\text { Unified: all } \\
\text { building } \\
\text { systems } \\
\text { made of } \\
\text { same } \\
\text { material. }\end{array}$ & $\begin{array}{l}\text { Primary } \\
\text { Generator: } \\
\text { Structure } \\
\text { defines the } \\
\text { aesthetics }\end{array}$ \\
\hline
\end{tabular}

In an academic environment, assuming that all the technical knowledge (Structures and services) possessed by a student at any stage of the program should be reflected and integrated into design solutions, the framework should enable to prioritize the parameters while evaluating their design solutions for integration. A review of syllabuses from 8 different schools reveals a pattern of Technical education. Table 4 and Table 5 show year wise normalized patterns for structures courses and Building Sciences courses respectively, for its ease of use in framework. 
Table 2: Comparing Different Integration Frameworks (Author, 2019)

\begin{tabular}{|c|c|c|c|c|c|}
\hline $\begin{array}{l}\mathbf{S} \\
\mathbf{N} \\
\mathbf{O}\end{array}$ & Genesis and Principles & $\begin{array}{l}\text { Building } \\
\text { Systems and } \\
\text { Sub-systems }\end{array}$ & $\begin{array}{l}\text { Dimensions and } \\
\text { Parameters }\end{array}$ & Evaluation Method & Scale \\
\hline \multirow{9}{*}{ 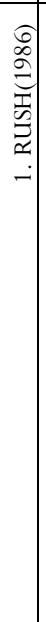 } & \multirow{9}{*}{$\begin{array}{l}\text { The building systems in different degrees and } \\
\text { combination of integration are evaluated for } \\
\text { three Dimensions: Performance ( } 6 \\
\text { parameters), Physical and Visible, whose } \\
\text { mandate is defined by physiological, } \\
\text { sociological, psychological and economic needs } \\
\text { or design limits of its acceptability. However, } \\
\text { Rush argues that economics plays a major role } \\
\text { in deliberating integration through conservation } \\
\text { of space, materials, time and Energy. Not all } \\
\text { the performances are critical; their priority is } \\
\text { defined by the nature of the building. }\end{array}$} & Building Exterior & Performance & \multirow{9}{*}{$\begin{array}{l}\text { Evaluating performance parameters by } \\
\text { comparing them with respective } \\
\text { standards and codes for attributes such } \\
\text { as workspace definition, accessibility, } \\
\text { adjacencies, air movement, } \\
\text { temperature, humidity, comfort zones, } \\
\text { heat transfers, air changes, air pollution, } \\
\text { acoustics, illuminance, Equivalent } \\
\text { sphere index, physical properties of } \\
\text { materials, U values, thermal absorption, } \\
\text { water and air tightness, color retention, } \\
\text { resistance to chemicals \& abrasion, bio- } \\
\text { attack, natural \& manmade disasters } \\
\text { and, building stability }\end{array}$} & \multirow{7}{*}{ 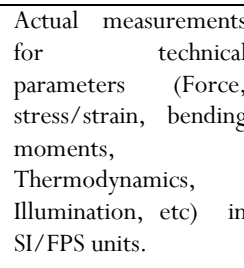 } \\
\hline & & Building Interior & \begin{tabular}{l|l} 
& Spatial \\
\end{tabular} & & \\
\hline & & Structure & Thermal & & \\
\hline & & Services & Ind.Air Quality & & \\
\hline & & \begin{tabular}{l|l} 
& $H V A C$ \\
\end{tabular} & Acoustical & & \\
\hline & & Plumbing & Visual (Light) & & \\
\hline & & $\begin{array}{l}\text { Electrical } \\
\text { Lighting }\end{array}$ & $\begin{array}{l}\text { Building } \\
\text { Integrity }\end{array}$ & & \\
\hline & & $\begin{array}{l}\text { Data } \\
\text { Telephone }\end{array}$ & Physical & & $\begin{array}{l}5 \text { point BISH Matrix } \\
\text { with scale (Separate, } \\
\text { Touching, connected, } \\
\text { meshed, union) }\end{array}$ \\
\hline & & $\begin{array}{l}\text { Vertical } \\
\text { systems }\end{array}$ & $\begin{array}{l}\text { Visuality } \\
\text { (Aesthetics/visual) }\end{array}$ & & $\begin{array}{l}5 \text { degrees - no visible } \\
\text { \& no change, visible \& } \\
\text { change, visible \& } \\
\text { surface change, visible } \\
\& \text { size/shape change, } \\
\text { visible with location/ } \\
\text { orientation change }\end{array}$ \\
\hline \multirow{7}{*}{ 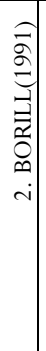 } & \multirow{7}{*}{$\begin{array}{l}\text { Uses the concept of 'Game Theory' to explain } \\
\text { the integration based on the stakeholder's } \\
\text { preferences and practical limitations. It is } \\
\text { developed for educational purposes with an } \\
\text { intention to apply it on the rough-sketch. A } \\
\text { two-level framework involves a predesign stage } \\
\text { for setting requirements for space, structures \& } \\
\text { environmental systems using building codes } \\
\text { and thumb rules, followed by a conceptual } \\
\text { design using inventory on basic quantitative } \\
\text { information about Building codes \& systems. }\end{array}$} & Building Interior & Performance & \multirow{7}{*}{$\begin{array}{l}\text { Using thumb rules, codes and 'ready to } \\
\text { refer' data sheets to establish nature and } \\
\text { capacity with approximate member } \\
\text { sizing for structural systems, HVAC } \\
\text { systems, electrical and plumbing } \\
\text { systems. Understanding the spatial } \\
\text { interaction of structural systems with } \\
\text { other Services }\end{array}$} & \multirow{7}{*}{$\begin{array}{l}\text { Actual measurement } \\
\text { for technica } \\
\text { parameters (Force } \\
\text { stress/strain, bending } \\
\text { moments, } \\
\text { Thermodynamics, } \\
\text { Illumination, etc.) in } \\
\text { SI/FPS units. }\end{array}$} \\
\hline & & Structures & \begin{tabular}{l|l} 
& Thermal \\
\end{tabular} & & \\
\hline & & Services & Ind.Air Quality & & \\
\hline & & \begin{tabular}{l|l} 
& $H V A C$ \\
\end{tabular} & Acoustical & & \\
\hline & & Plumbing & Visual (Light) & & \\
\hline & & $\begin{array}{l}\text { Electrical } \\
\text { Lighting }\end{array}$ & $\begin{array}{l}\text { Building } \\
\text { Integrity }\end{array}$ & & \\
\hline & & & & & \\
\hline \multirow{8}{*}{ 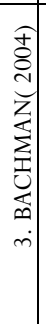 } & \multirow{8}{*}{$\begin{array}{l}\text { Hardware: integration among building systems; } \\
\text { software: integration in the design process; Is } \\
\text { an extension of Rush's framework on } \\
\text { integration with the inclusion of post-industrial } \\
\text { context including advancements in technologies } \\
\text { and digression in ideologies and new } \\
\text { typologies. } 3 \text { nonexclusive notions of } \\
\text { integration: physical, visual, and performance, } \\
\text { which translate into Shared space, shared } \\
\text { image, and shared mandates. }\end{array}$} & Building Exterior & Performance & \multirow{8}{*}{$\begin{array}{l}\text { Use of Location Data (Site, Normalized } \\
\text { Climate Data), Cost Data and } \\
\text { comparing with Building equipment and } \\
\text { material properties data for } \\
\text { performance in the light of design } \\
\text { intentions for different building } \\
\text { systems. No calculations involved. }\end{array}$} & \multirow{8}{*}{$\begin{array}{l}\text { No specific scale for } \\
\text { analyzing } \\
\text { performance, physical } \\
\text { or visual integration. } \\
\text { Uses actual } \\
\text { measurements in } \\
\text { SI/FPS units to refer } \\
\text { technical parameters. }\end{array}$} \\
\hline & & Building Interior & \begin{tabular}{l|l} 
& Spatial \\
\end{tabular} & & \\
\hline & & Structures & Thermal & & \\
\hline & & Services & Ind.Air Quality & & \\
\hline & & Site & Acoustical & & \\
\hline & & & Light & & \\
\hline & & & \begin{tabular}{|l|l|} 
Building \\
Integrity
\end{tabular} & & \\
\hline & & & Visual (Aesthetics) & & \\
\hline \multirow{10}{*}{ 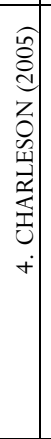 } & \multirow{10}{*}{$\begin{array}{l}\text { Structures as an architectural expression of a } \\
\text { building based on the designer's degree of } \\
\text { subjectivity and the potential of building } \\
\text { typology. Relating structures to attributes of } \\
\text { building form and exterior elevation such as } \\
\text { modulation, Depth and texture, Screening and } \\
\text { Filtering, Structural scale, entry and, } \\
\text { connection to building interiors. The functional } \\
\text { response of structural systems to building a } \\
\text { program, circulation, etc. as well as enhancing } \\
\text { building environmental performance for } \\
\text { parameters like light, sound, thermal } \\
\text { conductivity, etc. }\end{array}$} & Structure- Form & Performance & \multirow{10}{*}{$\begin{array}{l}\text { A Qualitative Evaluation of the different } \\
\text { parameters and building systems based } \\
\text { on the effect of structural systems on } \\
\text { the architecture of the building. }\end{array}$} & \\
\hline & & Building Elevation & \begin{tabular}{l|l} 
& Spatial
\end{tabular} & & structure; $\quad$ Three \\
\hline & & \begin{tabular}{l|l} 
& Modulation
\end{tabular} & Thermal & & categories of the \\
\hline & & $\begin{array}{l}\text { Depth \& } \\
\text { Texture }\end{array}$ & Acoustical & & $\begin{array}{lr}\text { relationship } & \text { between } \\
\text { Architecture } & \text { and }\end{array}$ \\
\hline & & $\begin{array}{l}\text { Screen'g \& } \\
\text { Filter'g }\end{array}$ & Light & & $\begin{array}{l}\text { structural form - } \\
\text { Synthesis, }\end{array}$ \\
\hline & & $\begin{array}{l}\text { Structural } \\
\text { Scale }\end{array}$ & $\begin{array}{l}\text { Building } \\
\text { Integrity }\end{array}$ & & $\begin{array}{l}\text { Consonance, } \\
\text { Contrast. }\end{array}$ \\
\hline & & \begin{tabular}{l|l} 
Entry \\
\end{tabular} & Visual (Aesthetics) & & \\
\hline & & Structure- Interior & & & \\
\hline & & \begin{tabular}{l|l} 
& Connections \\
\end{tabular} & & & \\
\hline & & Details & & & \\
\hline & Structural planning as a function of Building & Building Exterior & Performance & Horizontal spanning and vertical & Formal intent of \\
\hline 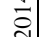 & design and program, codes, legal constraints, & Building Interior & Spatial & supports are discussed in detail with & structures systems in \\
\hline $\begin{array}{l}3 \\
\vdots \\
\vdots \\
Z\end{array}$ & $\begin{array}{l}\text { economic feasibility, systems integration, } \\
\text { zoning laws, building height, occupancy, }\end{array}$ & Structural Systems & $\begin{array}{l}\text { Building } \\
\text { Integrity }\end{array}$ & $\begin{array}{l}\text { ready-to-use or ready-to-refer data } \\
\text { sheets to provide a basic idea of member }\end{array}$ & $\begin{array}{l}\text { relation to architecture } \\
\text { evolves in three ways: }\end{array}$ \\
\hline 壱 & construction type, Fire rating and concepts of & Services & Physical & sizes in relation to span, the & Exposure, concealing \\
\hline & $\begin{array}{l}\text { continuity \& redundancy. Structural patterns as } \\
3 \text {-D compositions of horizontal spanning }\end{array}$ & & Visual (Aesthetics) & $\begin{array}{l}\text { arrangement of members and } \\
\text { materiality The lateral force resisting }\end{array}$ & \\
\hline & vertical support \& lateral bracing systems, with & & & systems, Large span structures and MEP & \\
\hline & attributes including Structural unit, a grid in a & & & services are discussed conceptually. & \\
\hline & $\begin{array}{l}\text { different scale, proportion, orientation \& } \\
\text { combination of geometries. Patterns in relation }\end{array}$ & & & & \\
\hline & to site constraints or spatial organization. & & & & \\
\hline
\end{tabular}


Table 3: Matrix Converted To Table With Dimensions, Parameters And Building Systems As Well As Indicators For Integration (Author 2019 (Adapted from Rush 1986, Bachman 2004, Charleson 2005, Ching 2014))

\begin{tabular}{|c|c|c|c|c|c|}
\hline \multirow{2}{*}{ 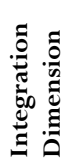 } & \multirow[b]{2}{*}{$\Omega^{2}$} & \multirow{2}{*}{ 童 } & \multicolumn{2}{|r|}{ Building Systems } & \multirow[t]{2}{*}{ Indicator } \\
\hline & & & & Sub-system & \\
\hline \multirow{21}{*}{ 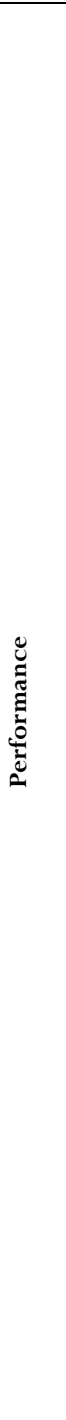 } & \multirow{7}{*}{\multicolumn{2}{|c|}{ 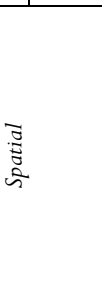 }} & \multirow[t]{2}{*}{ Exterior } & Form & General Structural system type and its material to determine the image, access and security \\
\hline & & & & Elevation & Structural patterns of system: unit/bay size, grid attributes \\
\hline & & & Interior & Volume \& spatial organization & $\begin{array}{l}\text { Structural pattern, Module/grid for spatial planning, layout and as a space divider. Adequate } \\
\text { Floor-to-Floor height. Sightlines. Flexibility in loading. }\end{array}$ \\
\hline & & & \multirow{4}{*}{ Services } & Electrical, Tel, data \& security & \multirow{3}{*}{$\begin{array}{l}\text { Adequate ceiling height. Flexible service module. Vertical shaft efficiency. Volumetric needs. } \\
\text { Module, volume, Number, Form, size, configuration and expansion capability of HVAC } \\
\text { Components: Generator size; Service conduits; service terminals; compartmentalization defined } \\
\text { for different groups based on demand. }\end{array}$} \\
\hline & & & & Lighting & \\
\hline & & & & $\begin{array}{l}\text { Plumbing (Water, Waste, Fire) } \\
\end{array}$ & \\
\hline & & & & Vertical Systems & Form, module, configuration, expansion capability \\
\hline & \multirow{10}{*}{ 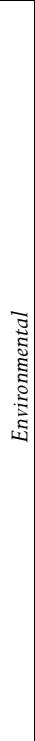 } & \multirow{2}{*}{$\underset{\overparen{E}}{\overparen{\Xi}}$} & Exterior & Form & $\begin{array}{l}\text { Proportions and scale of Form volume for air conditioning. Avoid thermal bridging. Horizontal } \\
\text { plan and orientation for cross ventilation. }\end{array}$ \\
\hline & & & & Elevation & Self-shading of windows by structure. Openings for solar access and shading. Vertical stratification \\
\hline & & \multirow{3}{*}{ 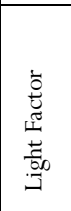 } & Exterior & Elevation & $\begin{array}{l}\text { Appropriate sun shading with structure \& other material. Reduction of contrast at openings, } \\
\text { diffusion of light. }\end{array}$ \\
\hline & & & Interior & Volume \& spatial organization & The structure as a light reflector. Daylight distribution affected by the structural component \\
\hline & & & Services & Lighting & $\begin{array}{l}\text { Appropriate bay sizes, to provide distribution of daylight and artificial light. Space for cabling and } \\
\text { to avoid shadows. Glare protection and shading. Flexible service module. Adequate ceiling height }\end{array}$ \\
\hline & & \multirow{3}{*}{ 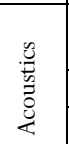 } & Exterior & Form & $\begin{array}{l}\text { Elimination of vertical acoustical migration paths. Avoiding concentrations and flutter caused by } \\
\text { form. Tightness against outer noise. }\end{array}$ \\
\hline & & & Interior & Volume \& spatial organization & Appropriate form/volume for sound distribution. The structure as a sound barrier. \\
\hline & & & Services & HVAC & Structure system and material to reduce vibrations at generator and conduits \\
\hline & & \multirow{2}{*}{ 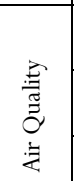 } & Exterior & Form & $\begin{array}{l}\text { Space for local mechanical air distribution. Leakproof structure. Elimination of vertical pollutants } \\
\text { migration }\end{array}$ \\
\hline & & & Interior & Volume \& spatial organization & $\begin{array}{l}\text { Structural height for adequate ceiling plenum space. The structure as a Barrier to outdoor and } \\
\text { indoor pollutants. }\end{array}$ \\
\hline & & \multirow{4}{*}{ 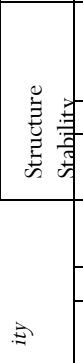 } & Exterior & Form & Use of structural components (horizontal spanning, vertical supports, lateral bracings and \\
\hline & కี & & & Elevation & membranes) for construction equipment and material support. \\
\hline & है & & Interior & Volume \& spatial organization & \\
\hline & $\tilde{\Xi}^{2}$ & & Services & Plumbing (Water, Waste, Fire) & $\begin{array}{l}\text { Structural components double as services components (generator, conduits, terminals, control } \\
\text { system) that further support construction/fabrication activity. }\end{array}$ \\
\hline \multirow{8}{*}{ 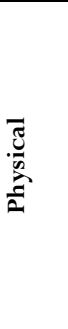 } & & & \multirow[t]{2}{*}{ Exterior } & Form & \\
\hline & & & & Elevation & the varying degree of union with non-structural elements of envelope, elevation and interior. It \\
\hline & & & Interior & Volume \& spatial organization & $\begin{array}{l}\text { becomes the visible defining form when unified with building exterior or interior. Structural } \\
\text { system and its relation to elements of building exterior or interior. Integration of walls, floors, } \\
\text { ceilings, equipment and furnishings with structural components. }\end{array}$ \\
\hline & & & Services & HVAC & Competing systems to occupy the same space. No overlapping in functions but serve \\
\hline & & & & Electrical, Tel, data \& security & technical/utilitarian function. Structural system, such as slab, columns, joists and trusses provide \\
\hline & & & & Lighting & opportunity via voids to accommodate service conduits and terminals. Structural systems provide \\
\hline & & & & $\begin{array}{l}\text { Plumbing (Water, Waste, Fire) } \\
\end{array}$ & support for mechanical services. \\
\hline & & & & Vertical Systems & \\
\hline & & & Exterior & Form & Structural system' relationship with "defining' attributes of form \& space such as ordering \\
\hline & & & & Elevation & principles, proportioning systems, scale, articulation of corner, edges and surfaces, enclosure \\
\hline & & & Interior & Volume \& spatial organization & $\begin{array}{l}\text { properties and spatial quality. Altering structure from its optimized position to suit architectural } \\
\text { requirements. }\end{array}$ \\
\hline$\stackrel{\overrightarrow{\underline{\omega}} .}{2}$ & & & Services & HVAC & Controlled visibility and accessibility of different components of mechanical systems for \\
\hline & & & & Electrical, Tel, data \& security & maintenance by structures. Mechanical systems and structure contributing to the aesthetics of space \\
\hline & & & & Lighting & both internally and externally. \\
\hline & & & & Plumbing (Water, Waste, Fire) & \\
\hline & & & & Vertical Systems & \\
\hline
\end{tabular}


Table 4: Normalized Knowledge And Expectations From Structures Courses For Parameter Selection Purposes In Assessment Of Integration Of Structures In Design Solutions (Author, 2019)

\begin{tabular}{|l|l|l|}
\hline Yr & Knowledge & \multicolumn{1}{|c|}{ Expectations } \\
\hline 1 & Fundamental & $\begin{array}{l}\text { Basic structural configuration to reflect equilibrium } \\
\text { of structures } \\
\text { and stability in spans, number and location of vertical } \\
\text { supports. Understanding of material properties is } \\
\text { minimal. }\end{array}$ \\
\cline { 1 - 1 } 3 & $\begin{array}{l}\text { Conceptual understanding of forces, loads, moments, } \\
\text { stresses in structural members. Structural } \\
\text { configuration starts exhibiting different grid patterns } \\
\text { and some reference to the material with its thickness. }\end{array}$ \\
\hline analysis of and & $\begin{array}{l}\text { Member sizing with reference to the structural design } \\
\text { structures }\end{array}$ & $\begin{array}{l}\text { systems complimenting design requirements. Using } \\
\text { codes and applying numerical models for the analysis } \\
\text { of structural design for statically determinate simple } \\
\text { buildings. }\end{array}$ \\
\cline { 3 - 4 } 4 & & $\begin{array}{l}\text { Conceptual understanding of statically indeterminate } \\
\text { systems including shells, domes, vaults, etc. }\end{array}$ \\
\hline
\end{tabular}

Table 5: Normalized Knowledge \& Expectations From Building Science \& Services Courses For Parameter Selection Purposes In Assessment Of Integration Of Structures In Design Solutions (Author, 2019)

\begin{tabular}{|l|l|l|}
\hline Yr & $\begin{array}{l}\text { Knowledge/ } \\
\text { subject }\end{array}$ & Expectations \\
\hline $1 \&$ & Climatology & $\begin{array}{l}\text { Passive solar architectural techniques including } \\
\text { orientation, shading devices. Use of natural daylight } \\
\text { and ventilation to thermal comfort advantage during } \\
\text { different times of the year in diverse climatic zones. } \\
\text { Heat load and U value calculations }\end{array}$ \\
\hline $3 \&$ & $\begin{array}{l}\text { Plumbing }- \\
\text { Water and } \\
\text { sanitation }\end{array}$ & $\begin{array}{l}\text { Understanding of different water and sanitation } \\
\text { systems in use at building, neighbourhood and city } \\
\text { levels. Concepts of hydrology for channelling } \\
\text { wastewater/rainwater discharge. Water requirements } \\
\text { and design of plumbing systems. Rainwater harvesting. }\end{array}$ \\
\cline { 2 - 4 } & $\begin{array}{l}\text { Acoustics, } \\
\text { HVAC, } \\
\text { Lighting, } \\
\text { mechanical } \\
\text { transportatio } \\
\text { systems } \\
\text { (lifts, etc) }\end{array}$ & $\begin{array}{l}\text { Acoustics as a function of form and materiality. } \\
\text { different acoustical requirements and control in } \\
\text { Artificial lighting and electrical wiring circuits for } \\
\text { buildings. Concepts of lux, illumination, voltage, } \\
\text { amperes, etc. for determining lighting requirements. } \\
\text { Design of different kinds of HVAC or mechanical } \\
\text { ventilation, cooling and heating systems. Thermal load } \\
\text { calculations.Lifts, escalators, travelators design based } \\
\text { on passenger load requirements as per codes. }\end{array}$ \\
\hline
\end{tabular}

Besides Structures, material understanding is also imparted through construction technology-related courses taught almost all the semesters of the program. For instance, the design of brick masonry arches, vaults, domes, and types of bonds is taught in the first and second year of the program. Design studios from the central core of the entire architecture program. They vary in scale and typology in every advancing semester. Table 6 provides project typologies and expectations for design projects in the first four years of architecture program, based on a review of syllabuses of 8 schools in India.

Table 6:: Normalized Project Types And Expectations From Architectural Design Courses For Parameter Selection Purposes In Assessment Of Integration Of Structures In Design Solutions (Author, 2019)

\begin{tabular}{|c|c|c|}
\hline Yr & Projects types & Expectations \\
\hline 1 & $\begin{array}{l}\text { Personal space, café, } \\
\text { observation decks, } \\
\text { Childcare centres, } \\
\text { Tod-lots, etc. }\end{array}$ & $\begin{array}{l}\text { Basic understanding attributes of form and } \\
\text { space and, its ordering principles. Use of } \\
\text { different volumes, shapes, colour and texture } \\
\text { in scale and proportion for a design for } \\
\text { massing. }\end{array}$ \\
\hline 2 & $\begin{array}{l}\text { Primary schools, small } \\
\text { resorts, house design, } \\
\text { memorials, haat and } \\
\text { small market place } \\
\text { designs, Guesthouses, } \\
\text { Religious buildings, } \\
\text { etc. }\end{array}$ & $\begin{array}{l}\text { Site planning issues, adjacencies with respect } \\
\text { to functional requirements of the building. } \\
\text { Response to the context. Integration with } \\
\text { structures, Climatology and building } \\
\text { construction. }\end{array}$ \\
\hline 3 & $\begin{array}{lr}\text { High rise } & \text { buildings, } \\
\text { institutional } & \text { buildings } \\
\text { including } & \text { senior } \\
\text { schools, } & \text { colleges; } \\
\text { Hospitality } & \text { buildings, } \\
\text { Malls, etc. } & \end{array}$ & $\begin{array}{l}\text { Building level Environmental concerns } \\
\text { including energy conservation, core design } \\
\text { with services, structural systems integration. } \\
\text { Use of passive techniques combines with } \\
\text { energy systems for achieving thermal comfort. }\end{array}$ \\
\hline 4 & $\begin{array}{l}\text { Housing, Airports and } \\
\text { transportation centres, } \\
\text { hospitals and hotels } \\
\text { design }\end{array}$ & $\begin{array}{l}\text { Broader urban design issues including massing } \\
\text { of blocks, site environmental and energy } \\
\text { conservation issues. Use of large-span } \\
\text { structures, the inclusion of services, resolution } \\
\text { of functional complexity through spatial } \\
\text { design. }\end{array}$ \\
\hline
\end{tabular}

(Tables 4, 5 and 6 Based on the Review of :(School of Planning and Architecture - New Delhi 2012; School of Planning and ArchitectureBhopal 2016; Indian Institute of Technology- Roorkee 2016; Ansal University 2012; University of Mumbai 2012; National Institute of Technology Raipur 2010; Anna University 2013; Council of Architecture India 2013a))

Certain Building typologies offer more integration of structural systems. For instance, large span structures such as bridges, exhibition halls, factories, etc. invariably integrate structures into their building exterior systems visually as well as spatially. This would affect the parameters selection criteria in the Assessment Framework for the evaluation of design solutions.

\subsubsection{Expert Opinion and Pretesting}

The author tested the framework for 11 designs solutions from $1 \mathrm{st}$ to 5 th years. Two designs each from $1^{\text {st }}$ to $4^{\text {th }}$ year and 3 design representing different typologies were selected from $5^{\text {th }}$-year Thesis projects of School of Planning and Architecture-Delhi (SPA-D) and Indian Institute of Technology -Roorkee (IIT-R). Knowledge levels according to syllabuses as wells as building typologies decided relevant parameters. Assessment Method involved reviews using student's design work- models, drawings, sketches, concept notes, approach, etc. It was felt that certain 
sub-parameters should be clubbed for the ease of use and availability of data.

Ten Experts included persons with expertise in pedagogy, teaching structures and design courses assessed 11 design samples from years 1 to 5 using Matrix in Table 2. The matrix was evaluated for its attributes of efficacy, efficiency, learnability, ease of use, and utility (completeness, comprehensibility, ambiguity, flexibility and usability) (Beecham et al. 2005; Siniscalco \& Auriat 2005; Matook \& Indulska 2009; Rittgen 2010). The Framework design was largely found to cover all the dimensions and aspects of integration with appropriate rating criteria and, suited for the academic environment. It was relatively easy to use and flexible enough to accommodate different studio projects. Experts, during discussions, further suggested a reduction in the number of data points by combining various sub-parameters for different building systems as it would be difficult to get data separately in an academic setting.

\subsubsection{Pre-Testing Data Analysis}

The framework was found to be flexible and can be customized as the student knowledge levels as well as information available from the student design projects data. The building sub-systems 'form and elevation' were collectively assessed for all the first and second-year designs as well as two thesis projects for evaluating their performance integration, due to lack of adequate information on building elevations since they were not resolved. Similarly, physical and visual integration was also collectively assessed for all the design sample for building exterior and interior systems, due to lack of adequate information. In the absence of any structural and material details for first and second year designs, the structure is assumed to be 9" thick load-bearing brick wall finished with plaster \& paint on both sides and, 4" to 6" thick RCC slab for vertical and horizontal or inclined planes/curves surfaces, which also becomes enclosure of spaces in the initial years. Such practice is a result of instruction of studio teachers to students to use 9" thick vertical members as enclosure and, students' knowledge about brick wall sections from their construction subject in initial years. Grid frame structures and other material such as RCC, steel and brick are only seen in design solutions of $3^{\text {rd }}$ and later years. Since services are not really resolved, even though they are considered for assessing $3^{\text {rd }}$ and later year design solutions, the structural provision is taken into account while evaluating integration such as adequate heights and location of service generator.

The assessment results for test samples are shown in Table 7, with similar format used for other samples in full scale study. The framework showed high spatial integration for all the projects from $1^{\text {st }}$ to $4^{\text {th }}$ years and stadium as well as space city thesis projects, since the 'structure' of the building is 'space' enclosing elements for first and second-year projects and supports spatial layout for the $3^{\text {rd }}$ year institutional and $4^{\text {th }}$ year housing projectsto the extent that spaces can't be altered thereafter. This is justifiable since the projects chosen are specialized with no or little option for open space planning. The scale also showed neutral spatial integration for thesis Museum project for customizable exhibition spaces, although regular structural grid supports the spatial organization. The integration of structures with other building systems for environmental performance is primarily assessed on building volume, size and location of openings, use of the structure as thermal mass, the height of floors and space below structures to allow for the passage of services. First to fourth-year designs had adequate opening sizes placed at right positions and orientations to allow for daylighting and air and, may also affect thermal comfort depending upon the climatic situation, with a structure not interfering in the location of openings.

Table 7: Assessment Results For Evaluating Integration Of Structures In Test Samples From Different Years (Author 2019)

\begin{tabular}{|c|c|c|c|c|c|c|c|c|c|c|c|c|c|c|c|}
\hline \multirow{2}{*}{ 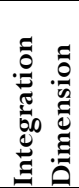 } & \multirow{2}{*}{ 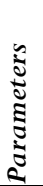 } & \multirow{2}{*}{ 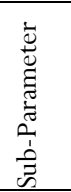 } & \multicolumn{2}{|c|}{ Building Systems } & \multirow{2}{*}{$\begin{array}{l}\text { Yr } \\
1 \\
1 \\
\end{array}$} & \multirow{2}{*}{$\begin{array}{l}\text { Yr } \\
1 \\
2 \\
\end{array}$} & \multirow{2}{*}{$\begin{array}{l}\text { Yr } \\
2 \\
\\
3 \\
\end{array}$} & \multirow{2}{*}{$\begin{array}{l}\text { Yr } \\
2 \\
\\
4 \\
\end{array}$} & \multirow{2}{*}{$\begin{array}{l}\text { Yr } \\
3 \\
5 \\
\end{array}$} & \multirow{2}{*}{$\begin{array}{l}\text { Yr } \\
3 \\
\\
6 \\
\end{array}$} & \multirow{2}{*}{$\begin{array}{l}\text { Yr } \\
4 \\
7 \\
\end{array}$} & \multirow{2}{*}{ 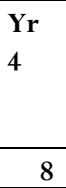 } & \multirow{2}{*}{$\begin{array}{l}\text { Yr } \\
5 \\
\\
9 \\
\end{array}$} & \multirow{2}{*}{$\begin{array}{l}\text { Yr } \\
5 \\
10 \\
\end{array}$} & \multirow{2}{*}{$\begin{array}{l}\text { Yr } \\
5 \\
11\end{array}$} \\
\hline & & & & Sub-system & & & & & & & & & & & \\
\hline \multirow{15}{*}{ 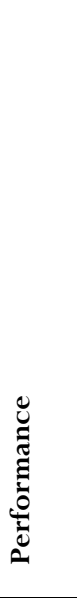 } & \multirow{8}{*}{\multicolumn{2}{|c|}{$\begin{array}{l}\bar{\Xi} \\
\bar{\Xi} \\
\text { n }\end{array}$}} & Exterior & Form & \multirow[t]{2}{*}{3} & \multirow[t]{2}{*}{3} & \multirow[t]{2}{*}{3} & \multirow[t]{2}{*}{3} & 2 & 2 & 3 & 3 & \multirow[t]{2}{*}{2} & \multirow[t]{2}{*}{4} & 4 \\
\hline & & & & Elevation & & & & & 3 & 2 & 2 & 3 & & & 4 \\
\hline & & & Interior & Volume \& spatial organization & 3 & 3 & 3 & 3 & 3 & 3 & 3 & 3 & 2 & 4 & 4 \\
\hline & & & \multirow[t]{5}{*}{ Services } & HVAC & \multirow[t]{4}{*}{ NA } & \multirow[t]{4}{*}{ NA } & \multirow[t]{4}{*}{ NA } & \multirow[t]{4}{*}{ NA } & \multirow[t]{4}{*}{2} & \multirow[t]{4}{*}{2} & \multirow[t]{4}{*}{2} & \multirow[t]{4}{*}{2} & \multirow[t]{4}{*}{2} & 3 & \\
\hline & & & & Electrical, Tel, data \& security & & & & & & & & & & & \\
\hline & & & & Lighting & & & & & & & & & & & \\
\hline & & & & Plumbing (Water, Waste, Fire) & & & & & & & & & & & \\
\hline & & & & Vertical Systems & NA & NA & NA & NA & 3 & 2 & 2 & 3 & 2 & 4 & 2 \\
\hline & & & Exterior & Form & 2 & 2 & 2 & 2 & 2 & 2 & 2 & 2 & 3 & 3 & 2 \\
\hline & & & & Elevation & & & & & 2 & 2 & 2 & 2 & 2 & 2 & 2 \\
\hline & & हี & Interior & Volume \& spatial organization & 2 & 2 & 2 & 2 & 2 & 2 & 2 & 2 & 2 & 2 & 2 \\
\hline & ปี & $E$ & Services & HVAC & NA & NA & NA & NA & 3 & 2 & 2 & 3 & 2 & 2 & 2 \\
\hline & 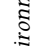 & & Exterior & Form & 3 & 2 & 3 & 3 & 3 & 2 & 2 & 2 & 3 & 3 & 2 \\
\hline & 芯 & $=0$ & & Elevation & & & & & 3 & 3 & 3 & 3 & 3 & 2 & 2 \\
\hline & & 离敢 & Interior & Volume \& spatial organization & 3 & 2 & 2 & 2 & 3 & 2 & 3 & 3 & 2 & 2 & 2 \\
\hline
\end{tabular}




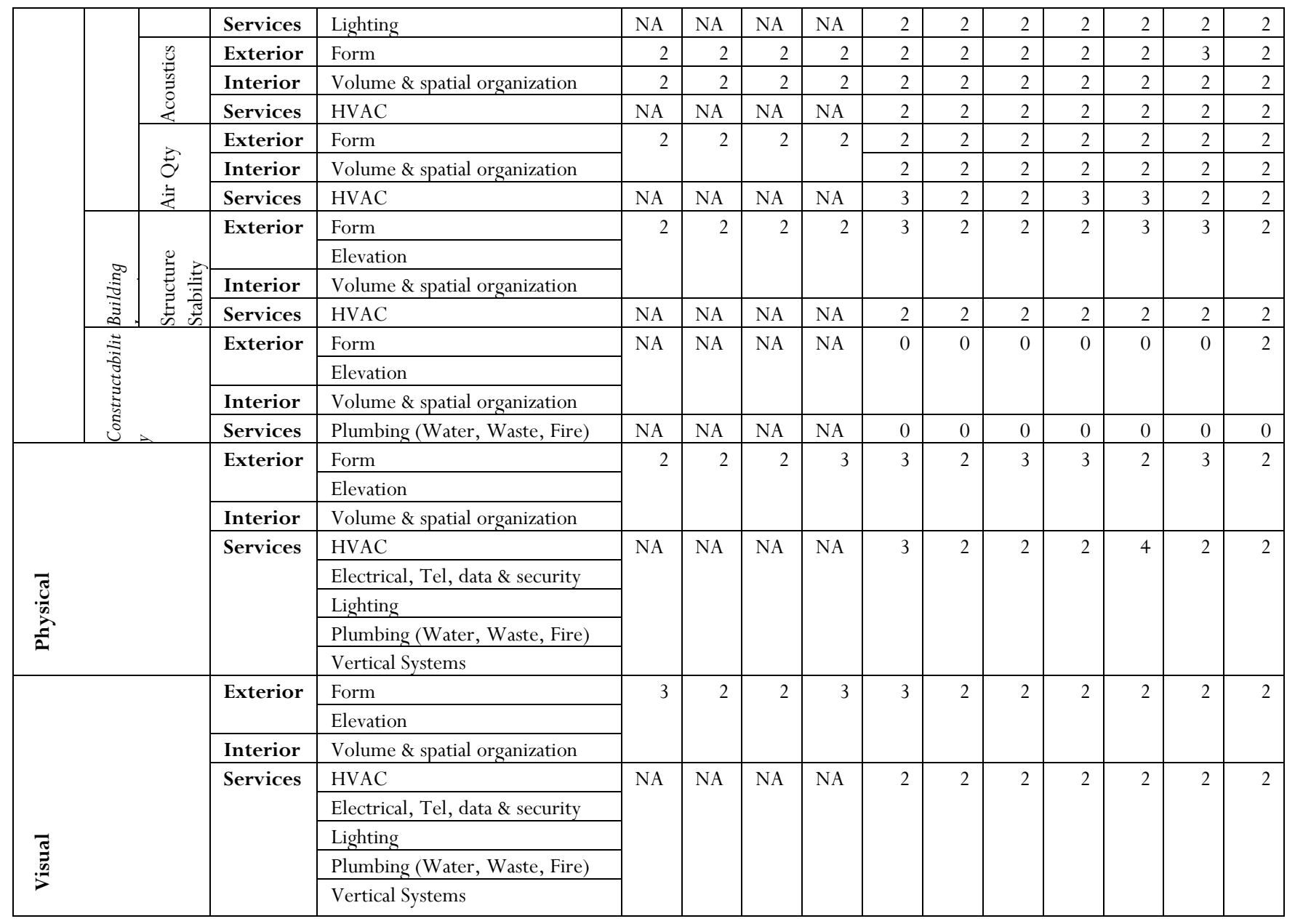

In Museum design thesis project, the student had touched upon climatic issues and sought to use features such as heavy walls, light-coloured flat and insulated roofs and screened porches and patios for Delhi climate with inclined roof for north light. First and second-year projects, though do not have any material or structural details satisfying idea of stability and strength, owing to their small spans. The third and fourth-year projects show details and resolution of the structural grid and materiality. Structural calculations for basic member sizing and analysis are worked out for thesis projects from IIT-R only. Constructability could only be assessed for Space city project since it involved structural modularity for construction as a major design component.

All the projects except a third-year project and Space city thesis projects have Building interior and exterior components made of either stone cladding or plaster with paint finish over brick walls or RCC/metal structure which exhibit 'Touching' level of physical integration. In of the third year project, building skin designed for environmental comfort comprises of a set of panels clad on to the frame that is 'connected' to the main building structure. The services are not worked for both $3^{\text {rd }}$ and $4^{\text {th }}$ years except for the placement of lifts that are well integrated with the structure. The 'Space city' thesis project has some complexity in wall section owing to the harsh outer environment that includes insulation and frame structure. The physical integration can be marked at 'meshed' level.

Structural system does not form the part of the building aesthetics for the first four years of projects as they are covered with plaster or stone. The thesis stadium project, the structural becomes part of aesthetics and to some extent defines it as well, especially for the roof structure. In the museum project, where a student wanted to make the building as a landmark for the city, there was a good opportunity for structural systems to address form specifically the roofs of halls and auditorium.

\subsection{Scaling up: Case Studies and Data Collection}

This research is designed as a cross-sectional study to understand if successive build-up in technical knowledge along with the nature of design studio mandates as well as the institutional environment affects the integration of structures in design solutions.

\subsubsection{Institutional Environment as Case studies Selection Criteria}

Relevance of Technical subjects in architecture education programs varies with the institutional context in which program was conceived and is currently administered -For instance 
Architectural schools in the west have orientations ranging from 'highly -Design discipline' oriented Beaux-Art inspired schools on one end of the spectrum to 'Engineering influenced' rationalist schools on the other end (Weatherhead 1941; Stevens 2017). Architectural education in India, though taken in diverse institutional contexts is homogeneously conceived, administered and regulated as course with a curriculum that is technically and vocationally orientated, with strong links to teaching by practitioners (Badrinarayan 2008). The Institutional context for Architectural education in India varies from 'Standalone' institutions with varying complexity of number \& type of programs by institutions like Schools of Planning and Architecture (SPA), CEPT University, Sir JJ College to the ones that form of the larger Traditional University system or technical institutions like Indian Institutes of Technology (IIT), National Institutes of Technology (NIT) that are highly dominated by engineering courses. 'Private vs. Public' may contribute to another dimension of Institutional context in architectural education, at least in India, since only $1 / 5$ of total Architecture institutions in India are government-run/aided (fully or partially) or public institutions(Council of Architecture India 2013b). Thus, three schools are chosen for the study: School of Planning and Architecture, New Delhi (SPA-D) - A standalone design institute; Sushant School of Art and Architecture, Gurgaon (SSAA) - A private School as part of larger Ansals University and; Indian Institute of Technology, Roorkee (IIT-R)- A technical University.

\subsubsection{Sample Size Criteria and Data Collection}

The annual intake of Architecture schools varies over ranges of 20, 30, 40, 60, 80, 100, 120 and 160 students per year (Council of Architecture India 2013b). Architectural schools with Batch sizes of 80 and above are divided into sections of 3040 students each. IIT-R annually admits between 30-40 students and therefore has one section. SPA-D with an annual intake of 120 students has three sections of 30-40 students each per batch. SSAA admits over 160 students per year and therefore has 4 sections per year with an average strength of 39-40 per year. It becomes clear from the above explanation that student strength per section at IIT-R and SPA-D vary between 28- 37 students and would govern the sample size. Nature of studio project and its operation logistics (individual vs group) governed 'section' selection criteria in case of SSAA and IIT-R. Preference was given to more resolved design projects and ones with structures and services resolution as part of the design mandate. Projects with less than six weeks of the working time were excluded from the potential sample domain. Given the choice, Individual projects were preferred over group work for a larger sample size of design project solutions. Table 8 shows details of Samples from different institutes across different years. In the table, project mandate and studio descriptions are mentioned to understand the studio orientation and project typology.

The premise that an increase in Technical knowledge per year in the architecture program may affect its integration into design solution requires an assessment of design solutions across the years. It would also require curricular data for design and Technical subjects for each case study to understand the amount as well as the duration of dissemination of knowledge. While design processes and its solutions are influenced by designer's background knowledge and skill that shapes his/her design orientation (Wiggins 1989), they are also affected by programmatic requirements and locational contexts (Tshumi 2005) and, is reflected in his/her concept note for design solutions. In the case of academic design exercises, studio Incharge/Teacher sets the mandate for design exercises elaborating on programmatic requirements including the level of resolution, area and functionality as well as other architectural concerns.

Table 8: Data Details for Assessment(Author, 2019)

\begin{tabular}{|c|c|c|c|c|}
\hline $\begin{array}{l}\text { Instituti } \\
\text { on and } \\
\text { Year }\end{array}$ & $\begin{array}{l}\text { Time } \\
\text { spent on } \\
\text { project } \\
\text { (weeks) }\end{array}$ & $\begin{array}{ll}\text { Studio } & \text { Project } \\
\text { Description } & \end{array}$ & $\begin{array}{l}\text { Samp } \\
\text { le size }\end{array}$ & $\begin{array}{l}\text { Project } \\
\text { mandate and } \\
\text { focus }\end{array}$ \\
\hline \multicolumn{5}{|l|}{$\begin{array}{l}\text { SPA- } \\
\text { D }\end{array}$} \\
\hline Year 1 & 10 & $\begin{array}{l}\text { A view deck for bird } \\
\text { sanctuary at Okhla, Delhi }\end{array}$ & 28 & Spatial \\
\hline Year 2 & 8 & $\begin{array}{l}\text { House design at Patel } \\
\text { Nagar, Delhi }\end{array}$ & 30 & Spatial \\
\hline Year 3 & 16 & $\begin{array}{l}\text { Institutional Building at } \\
\text { BHU, Varanasi }\end{array}$ & 30 & $\begin{array}{l}\text { Spatial, } \\
\text { Structural, } \\
\text { Environmental }\end{array}$ \\
\hline Year 4 & 16 & Chandigarh Airport & 26 & $\begin{array}{l}\text { Spatial, } \\
\text { Structural }\end{array}$ \\
\hline Year 4 & 16 & $\begin{array}{l}\text { Slum Rehabilitation and } \\
\text { Housing - Delhi }\end{array}$ & 15 & Spatial \\
\hline \multicolumn{5}{|l|}{ SSAA } \\
\hline Year 1 & 10 & Pavilions & 32 & Spatial \\
\hline Year 2 & 10 & $\begin{array}{l}\text { Gurgaon Habitat Center, } \\
\text { Aravalli Hills }\end{array}$ & 30 & Spatial \\
\hline Year 3 & 16 & $\begin{array}{l}\text { Architecture and Design } \\
\text { School, Aravalli Hills }\end{array}$ & 30 & $\begin{array}{l}\text { Spatial, } \\
\text { Environmental }\end{array}$ \\
\hline Year 4 & 16 & Housing - Gurgaon & 21 & Spatial \\
\hline \multicolumn{5}{|l|}{ IIT- R } \\
\hline Year 2 & 10 & Primary School- Roorkee & 26 & $\begin{array}{l}\text { Spatial, } \\
\text { Environmental }\end{array}$ \\
\hline Year 3 & 6 & Banquet Hall & 28 & $\begin{array}{l}\text { Spatial, } \\
\text { structural, } \\
\text { Services }\end{array}$ \\
\hline Year 4 & 10 & $\begin{array}{l}\text { Polar research institute, } \\
\text { Antarctica }\end{array}$ & 9 & $\begin{array}{l}\text { Spatial, } \\
\text { Structural, } \\
\text { Environmental }\end{array}$ \\
\hline
\end{tabular}

Data comprised of works of students' final design solutions that were presented to the jury. This included architectural drawings (plans, sections, elevations), concept notes, 3-D renderings and sketches, and, physical models. Structural grids and services drawings were also collected where they were available. The data pertaining to Design and Technical subjects in Case study schools was collected using a questionnaire instrument with information sources from syllabuses, group discussions with students and teachers with information pertaining to philosophical orientation of teacher, course organization, objectives, assessment methods and criteria, work-load, grading pattern, students' interest, Teacher's likeability, etc. 


\section{Discussion}

Project typologies that demand closed or customized plans for their functional areas greatly affect the spatial integration of structures with other building systems. As observed, it remains high (around level 3) for almost all the projects across three institutions except for SPA-D's $4^{\text {th }}$ year Airport Design project and partially for IIT-R's $3^{\text {rd }}$ year Banquet Hall project where the open space plans can be created. The Environmental performance on the integration of structure with another system largely remains neutral except in cases of daylighting as a result of structural roof element as seen in case of an SSAA's third-year architecture design project. In other cases, the structural system may not interfere with the openings sizes and position, which is largely a design and technical decision but to some extent is also guided by a structural grid frame. Furthermore, in case of services for environmental comfort, the structural system integrates by allowing for adequate below beam heights in academic designs solutions. The structural integrity is limited to conceptual understanding of stability and strength for the first two years and thereafter, structural patterns and materiality are integrated into design solutions but calculations do not form part of any design solution. Member sizing is done through thumb rules and no numerical analysis is done in any sample. The constructability does not become part of any design project throughout the sample size except a mention in IIT-R's $4^{\text {th }}$-year project on Polar institute. Perhaps this requires material approach or particular project typologies such as pre-fabricated structures or modular structures for its integration.

Physical integration is mostly of 'Touched' level for all the samples except ones from SPA-D $3^{\text {rd }}$ year institutional design and $4^{\text {th }}$-year Airport Design as well as IIT-R's $4^{\text {th }}$-year polar research institute. The brick wall with plaster and paint or cladding forms the outer wall and structural system with RCC slab or shell, although first two years design data do not explicitly mention the materiality or the structural system; it is only after the discussions with students and teachers that such facts are established. Some of the samples from SPA-D $3^{\text {rd }}$-year design and all of the $4^{\text {th }}$-year design solutions for Airport project show 'Connected' level of Physical integration between building exterior and structure. The external panels and framework are connected to the structure in the $3^{\text {rd }}$ year institutional project while glass walls are connected to steel columns and frame in Airport projects. IIT-R $4^{\text {th }}$ year polar institute show 'meshed' level of physical integration with structure occupying same space as thermal insulation and heating services along with building exterior and interior.

Project Building Typology plays a very important role in the visual integration of structures. It is evident from the fourth year project for Airport Design involved the use of large span structural systems. In Large span building typologies such as transportation centres, stadiums, bridges, hangars, industrial units, etc, structural system invariably become part of architectural aesthetics and in some cases, also lead them. More than 2/3 of design solutions (around 20) for Airport Design project showed active visual integration of structural systems into aesthetics. This is far more than average of 1 in 10 to 1 in
15 (2-3 designs per 30 samples) in all other studios different schools and years. While the Building typology played a major role in $4^{\text {th }}$ year Airport design project, Teacher's interest was crucial factor in pursuing integration of structural systems, as she called for special lectures by structural engineers to talk and discuss about possibilities of different structural systems as well as provide a critical input on structures of students' design solutions

Integration is a holistic idea that needs to be addressed through its different dimensions of Performance, physical and visual across different building systems and processes at each stage of design and construction. Academic environment, though limits the understanding of integration to building systems at a basic level can still sensitize students with various its aspect through design projects. The framework devised here for assessing design solution across the first 4 years of the B.Arch program across three different institutions reveals interesting facts that can further guide the formulation of studio projects across different years.

Perhaps in the only case, the effect of pedagogy based on the use of physical models in teaching structures was seen in SPA-D $1^{\text {st }}$ year design solutions. In addition, there was one common teacher for structures class and design studio. 6 students used structural logic to generate forms in their design using shells and cable-stayed structures, compared to an average of 1 in 10 to 1 in 15 per studio. In yet another case of third-year SPA-D studio, despite studio teacher have structures expertise, the visual integration achieved through structural complexity in grid frame structures remain to 2 design solutions. However, the resolution of structures was higher than other studios. It only shows that inclusion of structural systems, as an important requirement in design mandate and teacher's enthusiasm for structural systems integration, may not be critical for visual integration of such systems into design solutions. It finally comes down to a student's interest and building typology.

The effect of institutional environment can be observed instudio mandates. IIT-R's studio mandates for $2^{\text {nd }}$ year also focus on structural aspects, which is not the case with $2^{\text {nd }}$-year studios of SPA-D and SSAA. Similarly, the $3^{\text {rd }}$ and $4^{\text {th }}$-year studio of IIT$\mathrm{R}$ also require resolution of services besides structures. $3^{\text {rd }}$ and $4^{\text {th }}$ years of SPA-D require structural resolution while the only $4^{\text {th }}$ of SSAA had a structural resolution as one of its mandates. This only reinforces the belief that architecture departments placed or initiated from the technical insitutes actively tend to focus on the technical aspects of design in their programs. For instance, IIT - R's architecture and planning deparment has been actively discussing structural issues in their second year design projects and, HVAC/other services in their third year studios phenomenon uncommon to other two schools for their second and third studios. Rather structures becomes part of discussion in third year studios in SPA-D and SSAA, while services are only discussed in their $4^{\text {th }}$ year projects. 


\section{Conclusion}

The integration assessment framework has managed to give insights to the level and state of integration of structures in students' design solutions across the first four years in different institutional environments. This study tries to capture the essence of good teaching for technical subjects in very different environment of architectural education and, provide valuable information for Academics teaching structures and design courses to architecture students using both traditional and alternative practices. The findings revealed that including structural resolution in the design studio mandate may result in higher resolution of structures in design solutions but it is the building typology and student interest that may result in higher visual integration of structures in design solutions. Furthermore, the institutional environment effects can be seen in the setting of studio mandates where architecture school in technical campus laid more emphasis on resolutions of structures and services when compared to other architecture schools.

\section{References}

Anna University, (2013). B.Arch. Degree Curriculum and Syllabus. 175 .

Ansal University, (2012). Syllabus for Bachelors of Architecture.

Bachman, L.R., (2004). Integrated Buildings: The Systems Basis of Architecture,

Badrinarayan, S., (2008). Architectural Education in India-Reforming the Design Studio. School of Planning and Architecture, New Delhi.

Beecham, S. et al., (2005). Using an Expert Panel To Validate A Requirements Process Improvement Model. Request PDF. Journal of Systems and Software, 76(3): 251-275.

Billington, D.P., (1983). The Tower and the Bridge, The New Art of Structural Engineering, Princeton: Princeton University Press.

Black, R.G. \& Duff, S., (1994). A Model for Teaching Structures : Finite Element Analysis in Architectural Education. Journal of Architectural Education, 48(1): 38-55.

Borill, C. \& Bovill, C., (1991). Architectural Design: Integration of Structural and Environmental Systems, New York: Van Nostrand Reinhold, NYC.

Charleson, A.A.W., (2005). Structures as Architecture: A Sourcebook for Architects and Engineers, Elsevier. Available at: http: / / books.google.com/books?hl=en\&lr=\&id=mS8uVBWqjJoC\&p gis $=1$.

Ching, F.D.K., Onouye, B.S. \& Zuberbuhler, D., (2014). Building Structures Illustrated, John Wiley and Sons.

Chiuini, M., (2006). Less Is More: A Design-oriented Approach to Teaching Structures in Architecture. In the Building Technology Educators' Symposium. p. 205.

Council of Architecture India, (2013a). Minimum Standards of Architectural Education and Brief Syllabus. Rakesh Press- Delhi
Council of Architecture India, (2013b). Status With Intake of Architectural Institutions in India. 1-63.Rakesh Press- Delhi

Darke, J., (1979). The primary Generator And The Design Process. Design Studies, 1(1): 36-44.

Indian Institute of Technology- Roorkee, (2016). Syllabus for the Bachelors of Architecture, Indian Institute of Technology Roorkee Website. Available at: https: / /www.iitr.ac.in/academics/uploads/File/architecture_UG core course syllabi.pdf. Accesed on 20-4-2017

Jonassen, D.H., (1997). Instructional Design Models for WellStructured and Ill-Structured Problem-Solving Learning Outcomes. Educational Technology Research and Development, 45(1): 65-90. Available at: http: / / www.scopus.com/inward/ record.url?eid=2-s2.0 0031536336\&partnerID $=40 \& \mathrm{md} 5=4 \mathrm{~d} 744 \mathrm{cbd} 1 \mathrm{f} 8 \mathrm{e} 0 \mathrm{f0e} 3 \mathrm{bc} 6616 \mathrm{dc} 462 \mathrm{f}$ b02.

Matook, S. \& Indulska, M., (2009). Improving the Quality Of Process Reference Models: A Quality Function Deployment-Based Approach. Decision Support Systems, 47(1): 60-71.

Morgan, M. ed., (1960). Vitruvius: The Ten Books on Architecture, Dover Publications, NY.

National Institute of Technology Raipur, (2010). Syllabus for Five Years B.Arch Degree Course. Avaliable at: hppt: / / www.nitrr.ac.in/downloads/syllabus/Arch_Syllabus_NIT\%20 Scheme.pdf. Accessed on 24-04-2017

Rittgen, P., (2010). Collaborative Modeling: Roles, Activities and Team Organization. International Journal of Information System Modeling and Design, 1(3): 1-19.

Rush, R.D., (1986). The Building Systems Integration Handbook, AIA and John Wiley and Sons.

Salvadori, M., (1980). Why Buildings Stand UP, W.W. Norton \& Company, Inc, NYC and London.

Salvadori, M. \& Heller, R., (1986). Structure in Architecture, Prentice Hall.

School of Planning and Architecture-Bhopal, (2016). Syllabus for the Bachelor of Architecture, SPA Bhopal Website. Available at: http: / / www.spabhopal.ac.in/Syllabus.aspx. Accessed on 20-04-2017

School of Planning and Architecture - New Delhi, (2012). Syllabus for the Bachelor of Architecture, SPA Delhi website. Available at: http://spa.ac.in/writereaddata/Syllabus-2011 - except design.pdf. Accessed on 24-04-2017

Siniscalco, M.T. \& Auriat, N., (2005). Questionnaire Design: Quantitative Research Methods In Educational Planning. Paris: UNESCO International Institute for Educational Planning

Stevens, G., (2017). A History of Architectural Education in the West. Architectural Blatherations. 1-6.

Tshumi, B., (2005). Event Cities 3, Cambridge, Massachusetts: The MIT Press.

Uihlein, M.S., (2013). Architectural Engineering In The Curriculum : The Case Study on AE and its Relationship to Architecture University of Illinois at Urbana-Champaign. Building Technology Educator's 
Symposium -Tectonics of Teaching. 3-10.

Uihlein, M.S., (2015). Structural Integration in Practice: Constructing a Framework from the Experiences of Structural Engineers. Journal of Professional Issues in Engineering Education and Practice, 141(3), p.4014010.

$$
\text { Available }
$$

http: / / ascelibrary.org/doi/10.1061/\%28ASCE\%29EI.1943-

5541.0000224.

University of Mumbai, (2012). Syllabus for the Bachelor of Architecture, University of Mumbai website. Available at: http://www.sirjjarchitecture.org/syllabus.html. Accessed on 25-042017

Weatherhead, A., (1941). History of collegiate education in architecture in the United States. Columbia University.

Wiggins, G.E., (1989). Methodology in Architectural Design. Massachusetts Institute of Technology. Available at: http://dspace.mit.edu/handle/1721.1/14498. Accessed on 23-052017 